FILOZOFIA

Roč. 74, 2019, č. 10

DOI: https://doi.org/10.31577/filozofia.2019.74.10.8

\title{
TOMÁŠ DVOŘÁK a kol.: Epistemologie (nových) médií
}

Praha: Akademie múzických umění 2018, 272 s.

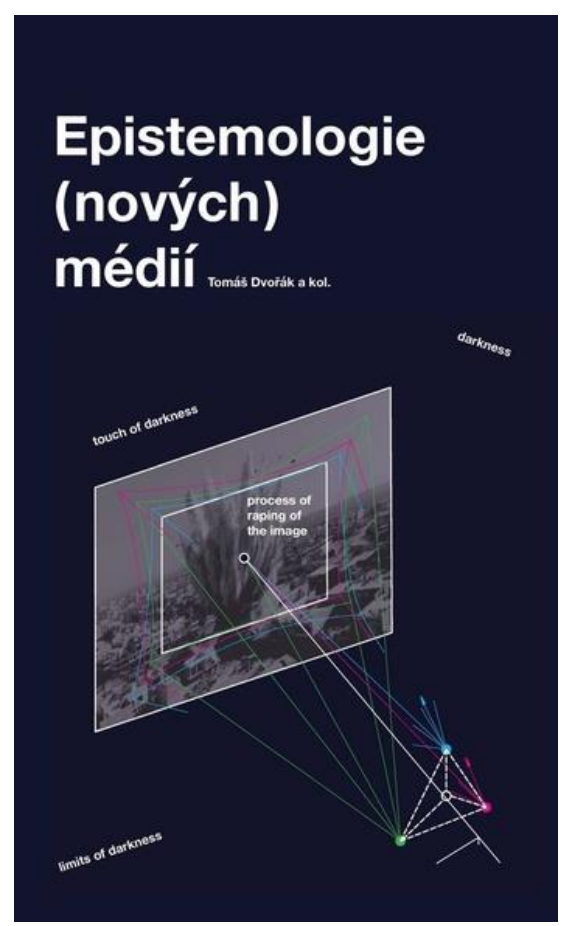

Tradičná epistemológia (aristotelovsko-tomistická) vychádzala z koncepcie zmyslového vnímania a následného rozumového poznania. Do tohto korešpondenčného systému poznania neskôr vel'mi výrazne prenikol jazyk, ktorý sa ešte $\mathrm{v}$ prvej polovici dvadsiateho storočia tejto schéme prispôsoboval, ako to vidíme napríklad u B. Russella alebo raného L. Wittgensteina, ale $\mathrm{v}$ druhej polovici dvadsiateho storočia, napríklad u neskorého L. Wittgensteina, sa stal východiskom pre konštruktivistické teórie poznania. Jazyk sa začal chápat' ako prostriedok nášho poznávania, ktorý sa len symbolicky vzt'ahuje k realite. Jazyk však nie je naším jediným, hoci privilegovaným médiom poznávania. $\mathrm{V}$ minulosti paralelne existovali médiá ako písmo, tlač, fotografia alebo telegraf a v súčasnosti sú to najmä nové médiá, ${ }^{1}$ ktoré významným spôsobom ovplyvňujú naše poznanie. Výrazný vplyv nových médií na súčasnú epistemológiu si uvedomili aj českí autori (M. Magidová, T. Jirsa, L. Likavčan, T. Dvořák, M. Vanžura, T. Chudý), ktorí zostavili kolektívnu monografiu s názvom Epistemologie (nových) médií (2018). V rámci nej rozoberajú rôzne aspekty vplyvu nových médií na naše poznanie. M. Magidová skúma novost' médií v umení, T. Jirsa videoklip, L. Likavčan digitálne infraštruktúry, T. Dvořák dejiny operačného

\footnotetext{
${ }^{1}$ V českom akademickom prostredí sa ustálil názov L. Manovicha „,nové médiá“, hoci ten nie je najpresnejší, lebo nové médiá starnú a prichádzajú d’alšie nové médiá. Možno by bolo presnejšie hovorit' o digitálnych médiách. V tomto prípade digitálny kód 1 a 0 stále zostáva, a to napriek dynamickým zmenám v komunikačných technológiách.
} 
strediska, M. Vanžura epistemológiu dronu a T. Chudý médiá ako banky pozornosti.

Markéta Magidová v prvej kapitole s názvom Novost (médii) v umění skúma významný epistemologický pojem novosti v umení a vo vede. Poukazuje na samotnú híbku novosti, ktorá súvisí s bytím človeka, jeho existenciou a slobodnou tvorbou $(2018,56)$. Pritom si však uvedomuje, že niečo nové nie je absolútne nové, lebo vždy nadväzuje aj na niečo predchádzajúce, tradičné a stereotypné. Autorka však nezabúda poznamenat', že všetko nové nemusí byt' nevyhnutne aj dobré, a taktiež že hranica medzi dobrou a zlou novost'ou býva často zahmlená $(2018,30)$. Nové médiá, ktoré sú takisto výsledkom l'udskej invencie, sú však už do takej miery autonómne, že sú schopné prebrat' na seba akciu, kombinovat', ponúknut' nové možnosti a v súčinnosti s človekom aj inovovat'. Na druhej strane prepojenie človeka s novými technológiami má aj svoje riziká, lebo mysel' človeka sa musí novým médiám prispôsobit', čo má vplyv na zmeny v kognitívnych schopnostiach človeka. ${ }^{2}$ Autorka sa odvoláva na M. Fishera a L. Manovicha, ked' tvrdí, že „študenti nie sú schopní sústredit' sa na jednu činnost', čítat' (dlhšie) texty alebo štrukturovat' svoje myslenie... a bez jazyka budeme komunikovat' pomocou gest, pohybov tela a mimiky ako naši predkovia v praveku“ $(2018,34)$. Tieto závery pokladám za vel’mi významné pre súčasnú výchovu a vzdelávanie.

Tomáš Jirsa v druhej kapitole s názvom Videoklip a jeho afektivní myšlení dějin novým spôsobom skúma epistemológiu dejín. Na základe viacerých videoklipov, v ktorých sa sprítomňujú historické udalosti, poukazuje na zrútenie temporality a afektívne prežívanie historickej udalosti $(2018,106)$, čo je myslenie mimo rámca tradičnej historiografie $(2018,107)$. Autor dokonca hovorí o obrate k afektívnemu prežívaniu histórie $(2018,106)$. S týmito tvrdeniami možno súhlasit', lebo nové médiá samy osebe rozkladajú lineárny čas. V kontexte kyberkultúry podobne hovorí o rozklade lineárneho času aj P. Lévy (2000, 229): „Kyberkultúra stelesňuje horizontálnu, simultánnu, čisto priestorovú formu prenosu. Prepojenie v čase je len sprievodným javom. Jej hlavná

\footnotetext{
${ }^{2} \mathrm{O}$ zmenách v kognitívnych schopnostiach človeka pod vplyvom používania digitálnych médií píšu autori S. Gálik a S. Gáliková Tolnaiová v článku Influence of the Internet on the Cognitive Abilities of Man. Phenomenological and Hermeneutical Approach (2015). Podobné úvahy sú rozvíjané aj v článku S. Gálika Influence of cyberspace on changes in contemporary education (2017).
} 
činnost' je prepájat' v priestore..." a navyše špeciálny prípad videoklipu na základe obrazov a hudby umocňuje afektívne prežívanie sprítomnenej historickej udalosti.

V tretej kapitole s názvom Vidèt jako platforma: politická epistemologie digitálnich infrastruktur Lukáš Likavčan skúma digitálne infraštruktúry a ich vplyv naše myslenie a poznávanie. Pod digitálnymi infraštruktúrami autor rozumie napríklad pouličnú signalizáciu, logistické siete, datacentrá a podobne. Ich základnou organizačnou jednotkou sú platformy, čo sú systémy, s ktorými môžeme interagovat'. Autor $(2018,122)$ tvrdí, že infraštruktúry a platformy formujú naše myslenie a poznanie: „Infraštruktúry vždy určujú, aké sú hranice a možnosti vášho konania $v$ danej situácii, a v konečnom dôsledku tak tvarujú váš život, a takisto aj myslenie.“ V prípade platforiem, akou je napríklad Google, hovorí podobne $(2018,123)$ : „Google tým, že facilituje používanie webového prostredia, ho zároveň aj formátuje a štandardizuje.“ A naše myslenie sa, samozrejme, tomuto trendu prispôsobuje. Autor zdôrazňuje, že infraštruktúry a platformy majú významný vplyv aj na politiku, pričom ako príklad uvádza konflikt medzi Kostarikou a Nikaraguou, pri ktorom došlo k posunutiu hraníc na Google Maps. Možno súhlasit's autorom, že epistemológia digitálnych infraštruktúr je previazaná aj s mocou a ich prenikanie do suverenity štátu môže predstavovat' aj politicko-ekonomické riziká.

Tomáš Dvořák v štvrtej kapitole s názvom Malé dějiny operačního střediska skúma vzt’ah medzi epistemológiou a mocou na pozadí dejín operačného strediska. Počiatky operačného strediska autor nachádza v byrokratickom stroji v polovici osemnásteho storočia vo Francúzsku $(2018,162)$. Tento stroj bol určený na policajné účely, konkrétne na evidenciu obyvatel'stva v Paríži. Zlatý vek operačného strediska podl'a autora nastáva $v$ druhej polovici dvadsiateho storočia, ale s paralelným rozvojom informačných a digitálnych technológií sa postupne mení z centralizovanej na decentralizovanú podobu. Autor sa odvoláva na G. Deleuza, ked' tvrdí, že s týmto prechodom súvisí aj prechod od disciplinárnych spoločností k spoločnostiam kontroly $(2018,181)$. Tým zároveň dochádza aj k zmenám epistemických praktík a ideálov. Autor sa odvoláva na V. Flussera, pričom tvrdí, že povaha vedenia sa mení, virtualizuje, a to $\mathrm{v}$ závislosti od výrokov a obrazov, ktoré sa vzt'ahovali $\mathrm{k}$ realite, $\mathrm{k}$ výrokom a obrazom, za ktorými už nie je nič určité $(2018,182)$.

Marek Vanžura sa v piatej kapitole s názvom Epistemologie dronů zaoberá vznikom a vývojom vojenských a civilných dronov v kontexte epistemológie 
a etiky. Charakteristickým znakom epistemológie dronov je podl'a autora vtáčia perspektíva a odtelesnené videnie $(2018,200)$. Autor však tvrdí, že by bolo mylné domnievat' sa, že „videnie“ dronov je neomylné a rovnaké ako l'udské videnie $(2018,204)$, čo sa dá demonštrovat' aj na tragických omyloch vojenských dronov. Dron jednoducho nevidí v perspektíve ako l'udské oko a situáciu vyhodnocujú algoritmy vložené do programu drona. Autor zároveň tvrdí, že pri dronoch ide o pomerne silné spojenie epistemologickej stránky s morálnou (napríklad pri vojenských dronoch môže íst' o špionáž, pri civilných o voyeurstvo), čo sa pri vývoji dronov aj v budúcnosti bude musiet' brat' do úvahy.

Tomáš Chudý v šiestej kapitole s názvom Média jako banky pozornosti skúma epistemologický problém vnímania, osobitne pozornosti. Pozornost’ v záplave informácií sa podla neho stáva čoraz vzácnejším kapitálom a médiá musia súperit' o pozornost' človeka. Ako hovorí T. H. Eriksen $(2009,28)$ : „V informačnej spoločnosti už nedostatkovým tovarom nie je železná ruda alebo vrecia s obilím, ale pozornost' ciel'ovej skupiny.“ Nie je preto náhoda, že pozornost' sa stáva kapitálom a za pozornost' sa platí. Ak napríklad niekto chce uverejnit' reklamu v televíznom prime time, tak za ňu musí zaplatit' najviac, lebo ide o najväčšiu koncentráciu pozornosti. Médiá podl'a Chudého $(2018,240)$ pracujú s pozornost'ou podobne ako banky, musia rátat's vkladom (koncentráciou), ale aj výdajom pozornosti. Tak isto sa tu uplatňuje princíp relevantnosti, lebo niektoré informácie si zaslúžia pozornost', a iné nie $(2018,255)$. Možno súhlasit's autorom, že súčasné informačné pret’aženie prináša nebývalý tlak na pozornost', a to nielen u recipientov, ale najmä v médiách, $\mathrm{z}$ ktorých sa stávajú banky pozornosti.

Na záver treba povedat', že všetky príspevky autorov sú zaujímavým a originálnym vkladom do epistemológie nových médií a spolu vytvárajú pomerne komplexný pohl’ad na skúmanú problematiku. Viac-menej sa v nich potvrdzuje, že epistemológia pod vplyvom nových médií prechádza radikálnymi zmenami a že režim pravdy ešte väčšmi závisí od ,praxe, spôsobov zhromažd'ovania a vyhodnocovania informácií, techník argumentácie, dokazovania a presvedčovania“ $(2018,8){ }^{3} \mathrm{Z}$ tohto dôvodu je kolektívna monografia prínosná nielen pre oblast' filozofie médií, respektíve epistemológie médií, ale aj pre iné spoločenské a humanitné vedy.

Slavomír Gálik

\footnotetext{
${ }^{3} \mathrm{~K}$ tomu pozri prácu od S. Gálikovej Tolnaiovej Media and Truth in the Perspective of the Practice and Life Form of the Modern "Homo Medialis" (2019).
} 


\section{Literatúra}

DVOŘÁK, T. a kol. (2018): Epistemologie (nových) médií. Praha: Akademie múzických umění.

ERIKSEN, T. H. (2009): Tyranie okamžiku. Rychlý a pomalý čas v informačním věku. Brno: Doplněk.

GÁLIK, S. (2017): Influence of cyberspace on changes in contemporary education. Communication Today, 8 (1), 30 - 39.

GÁLIK, S., GÁLIKOVÁ TOLNAIOVÁ, S. (2015): Influence of the Internet on the Cognitive Abilities of Man. Phenomenological and Hermeneutical Approach. Communication Today, 6 (1), 4- 15.

GÁLIKOVÁ TOLNAIOVÁ, S. (2019): Media and Truth in the Perspective of the Practice and Life Form of the Modern "Homo Medialis". Communication Today, 10 (1), 4 - 19.

LÉVY, P. (2000): Kyberkultura. Praha: Karolinum.

Slavomír Gálik

Katedra masmediálnej komunikácie

FMK Univerzity sv. Cyrila a Metoda v Trnave

Nám. J. Herdu 2

91701 Trnava

Slovenská republika

e-mail: slavomir.galik@ucm.sk

ORCID ID: https://orcid.org/0000-0002-8404-6297 